\title{
An Unusual Type of Casinghead Gasoline
}

\author{
By C. E. Coates ${ }^{2}$ and B. Y. Tims \\ Loutsiana State University, Baton Rouge, Louisiana
}

Gas from the Terrebonne Gas Field, about twenty miles below Houma, La., is piped to the town for use as a fuel. The condensate which forms in the pipes is the subject of the investigation recorded in this paper. It differs from ordinary casinghead gasoline in boiling point and other properties. Fractional distillation gives products of fairly constant boiling points, the lowest fraction having the formula $\mathrm{C}_{12} \mathrm{H}_{22}$. The condensate contains no paraffin hydrocarbons and is probably made up of dicyclopentyl, $\mathrm{C}_{10} H_{18}$, and its homologs.

$\mathrm{T}$ HE gas wells of Louisiana, and for that matter, gas wells in general have, during the last few years, been yielding, not only gas, but a fairly large quantity of a very light gasoline. The amount of this gasoline depends upon the nature of the gas, that yielding very little being called dry gas; that yielding considerable being called wet gas. It is commercially profitable to extract this gasoline down to a certain minimum content. Extraction was formerly accomplished at the well by compressing the gas, cooling the compressed gas, drawing off the condensed gasoline and allowing the rernaining gas to expand around tubes containing the incoming gas, thus cooling the latter. This process took place at the head of the well, and the product was hence called casinghead gasoline. At present it is considered cheaper to pass the wet gas through a heavy nonvolatile mineral oil, which absorbs the gasoline and from which the gasoline may be subsequently recovered by steam distillation, the oil being returned to process. This casinghead gasoline is exceedingly volatile, and is ordinarily mixed with somewhat high gravity gasolines, in order to make them more readily ignited in an internal combustion engine.

The only considerable deposits of gas in South Louisiana occur in the Terrebonne field, located about twenty miles south of Houma. In this field three producing wells have been, for a number of years, delivering gas at a pressure of about $1200 \mathrm{lbs}$. per sq. in. at the well. This gas is carried by pipes to Houma and its vicinity, and to the various sugarhouses in that section. The gas appeared to be wet, because quantities of a liquid condensed in the pipes in Houma and had to be collected in drips and removed at intervals. This liquid was considered casinghead gasoline, and was mixed with ordinary gasoline for use in automobiles in Houma. It, however, showed certain properties not possessed by ordinary gasoline, and for this reason $\mathrm{Dr}$. C. M. Menville, at the request of Dr. Coates, collected and sent to his laboratory about 2 gal. of the crude condensate.

\section{Physical Properties}

The oil was light in color and slightly fluorescent, and had an odor like pine oil, or oil of cedar. On analysis it gave values listed in Table I.

$\begin{array}{ll}\text { TABLE I } \\ \text { Refractive index at } 17^{\circ} \mathrm{C} . & =1.4590 \\ \text { Specific gravity } & =0.84819 \text { at } 24.5^{\circ} \mathrm{C} . / 24.5^{\circ} \mathrm{C} \text {. } \\ \text { Flash point } & =61^{\circ} \mathrm{C} \text {. } \\ \text { Burn point } & =63^{\circ} \mathrm{C} \text {. } \\ \text { Cold point } & =\text { below }-7^{\circ} \mathrm{C} . \\ \text { Viscosity at } 25.5^{\circ} \mathrm{C} . & =1.22 \\ \text { B.t. } t . & =19.363 \\ \text { Per cent sulfur } & =1.09\end{array}$

1 Presented before the Section of Petroleum Chemistry at the 62nd Meeting of the American Chemical Society, New York, N. Y., September 6 to 10,1921 .

2 Dean of Audubon Sugar School, and Head Professor of the Department of Chemistry.
The flash point determination was carried out in an open cup, heat was applied very gradually, and the process repeated a number of times.

In burning, the gasoline gave off heavy, black smoke with an unpleasant odor.

The heating value of the gasoline was determined in an Emerson bomb calorimeter. Sulfur was determined from the washings of the bomb.

\section{Distillation}

For the distillation, $500 \mathrm{cc}$. of gasoline were taken. Vaporization began at about $50^{\circ}$, and actual distillation at about $94^{\circ} \mathrm{C}$. Only a few cubic centimeters came over between $94^{\circ}$ and $100^{\circ} \mathrm{C}$. The temperature then rose suddenly to $195^{\circ} \mathrm{C}$, after which the distillation proceeded steadily. The distillate was collected in $2^{\circ}$ fractions. All the fractions were colorless except the last two, which were slightly fluorescent. A small amount of tarry matter remained in the flask after distillation was complete. At $226^{\circ} \mathrm{C}$., heavy vellow fumes were given off and no more distillate came over. Table II gives the results of distillation.

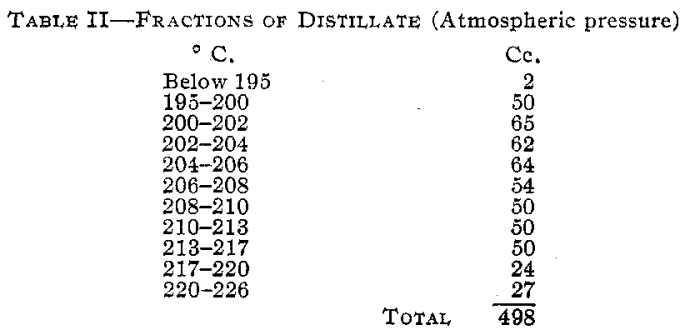

The fractions were purified by shaking with concentrated sulfuric acid, separating the oil, washing with water, shaking with sodium carbonate, decanting, and removing the excess water with powdered calcium chloride. The acid treatment removed a considerable amount of tarry matter. After purification, the turpentine-like odor of the original gasoline was greatly lessened, although it persisted in spite of acid treatment and subsequent redistillations.

REFRACTIONATION-The fractions, after purification, were distilled separately. The temperature of distillation varied in each case from $10^{\circ}$ to $30^{\circ} \mathrm{C}$. from that of the distillation temperature of the fraction. For lack of time, only the first three fractions, $200^{\circ}$ to $202^{\circ}, 202^{\circ}$ to $204^{\circ}$, and $204^{\circ}$ to $206^{\circ}$ (in all $100 \mathrm{cc}$.), were redistilled in this way in a 200 cc. flask. As distillation in all cases seemed to cause a slight decomposition, it was carried on in this case under a vacuum of $61 \mathrm{~mm}$., but even here there was decomposition. About $20 \mathrm{cc}$. of a brown liquid remained, but the fraction coming over from $207.5^{\circ}$ to $209.5^{\circ} \mathrm{C}$. was waterwhite and was taken for the subsequent work. It still had the odor of cedar or pine oil and contained no sulfur. Treated with bromine at the laboratory temperature of $25^{\circ}$, it seemed to behave as a saturated compound. Upon redistillation at $61 \mathrm{~mm}$., it gave a water-white fraction for which the analytical results in Table III were obtained. For sake of comparison, they are tabulated against some figures obtained by Coates, who was working on a fraction obtained from the Jenning oil. In calculating molecular refraction, the formula of Lorentz and Lorenz was used.

From these data it will be evident that this condensate 